\title{
Analisis kualitas airtanah pada musim kemarau di Pulau Koral Panggang, Kepulauan Seribu, Jakarta, Indonesia
}

\author{
Ahmad Cahyadi $^{1}$, Hendy Fatchurohman ${ }^{2}$, Indra Agus Riyanto ${ }^{3}$ \\ ${ }^{1}$ Department of Environmental Geography, Faculty of Geography, Universitas \\ Gadjah Mada, Yogyakarta, Indonesia \\ ${ }^{2,3}$ Master Program on Planning and Management of Coastal Area and Watershed, \\ Faculty of Geography, Universitas Gadjah Mada, Yogyakarta, Indonesia \\ *ahmadcahyadi@geo.ugm.ac.id
}

\begin{abstract}
Pulau Koral Panggang adalah pulau dengan ukuran sangat kecil (kurang dari 100 $\mathrm{km}^{2}$ ) dengan kepadatan penduduk yang paling tinggi di Kepulauan Seribu, Jakarta. Pulau Koral Panggang memiliki sumberdaya air yang sangat terbatas seperti pulau sangat kecil lainnya di dunia. Kondisi tersebut akan semakin parah pada musim kemarau. Penelitian ini bertujuan untuk menganalisis kualitas airtanah pada musim kemarau di Pulau Koral Panggang. Analisis kualitas airtanah dianalisis berdasarkan karakteristik fisika, kimia dan biologi dan membandingkannya dengan baku mutu air minum di Indonesia. Hasil analisis menunjukkan bahwa tingkat salinitas airtanah pada musim kemarau berdasarkan nilai daya hantar listrik mulai dari agak payau sampai dengan asin. Berdasarkan pada standar kualitas air minum, beberapa parameter melebihi baku mutu, seperti Kalsium, magnesium, Kalium, Natrium, Klorida, BOD, COD dan Coliform total. Hal ini mengindikasikan bahwa airtanah di Pulau Koral Pramuka telah mengalami pencemaran dari intrusi air laut dan limbah domestik.
\end{abstract}

\section{Introduction}

Pulau sangat kecil adalah pulau dengan ukuran kurang dari $100 \mathrm{~km}^{2}$ [1,2]. Pulau dengan ukuran sangat kecil memiliki masalah umum berupa terbatasnya sumberdaya air $[3,4,5]$. Beberapa hal yang menyebabkan sumberdaya air di pulau sangat kecil terbatas adalah (1) luas tangkapan hujan yang kecil, (2) curah hujan yang umumnya lebih rendah dibandingkan dengan pulau besar, (3) adanya pengaruh intrusi air laut karena keberadaanya yang dikelilingi oleh laut dan (4) tidak adanya imbuhan atau aliran airtanah dari wilayah lain $[1,2,6,7,8,9]$.

Pulau koral Panggang yang terletak di Kepulauan Seribu, DKI Jakarta, Indonesia (Gambar 1) merupakan salah satu pulau sangat kecil. Secara geologi pulau koral ini merupakan patch reef dengan batuan dasar berupa gamping dan bagian permukaan terdiri atas material bioklastis [10]. Pulau koral ini merupakan pulau dengan kepadatan paling tinggi di antara 100-an pulau lain di Kepulauan Seribu. Hal ini karena pulau koral ini adalah pulau koral yang dihuni pertama kali di Kepulauan Seribu. Luas pulau koral ini hanya sekitar 9 hektar, dan jumlah penduduknya sekitar 4.000 orang [11]. Kepadatan penduduk yang tinggi juga nampak dari dominannya penggunaan lahan permukiman di pulau koral ini, yakni sampai dengan $74 \%$ luas pulau koral ini [12]. 


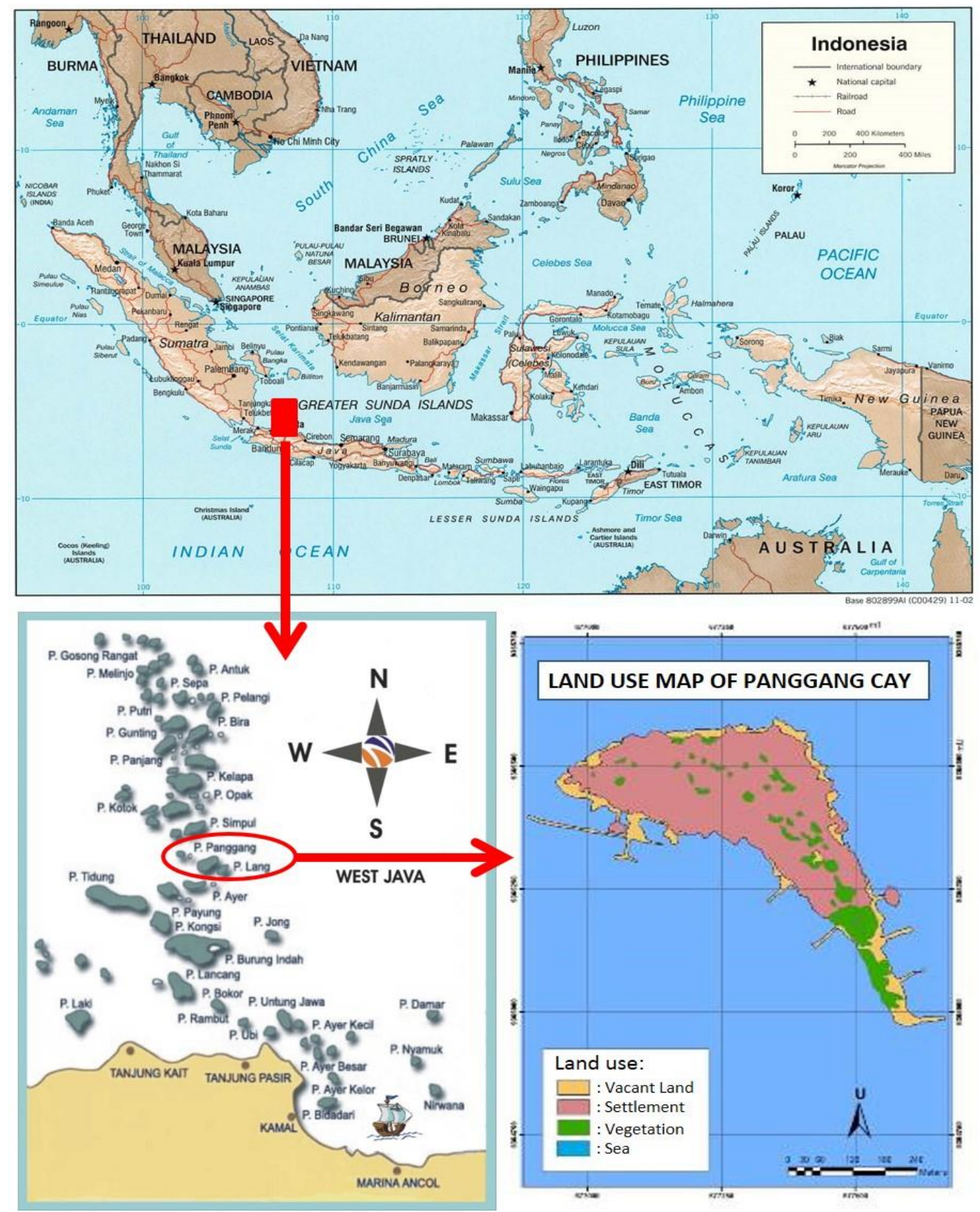

Gambar 1. Lokasi Penelitian

Meskipun memiliki luas wilayah yang terbatas, jumlah penduduk di Pulau Koral Panggang terus bertambah dari tahun ke tahun [11]. Hal ini tentunya akan menyebabkan semakin banyaknya sumberdaya yang digunakan. Salah satu sumberdaya yang harus mendapatkan perhatian khusus adalah sumberdaya airtanah $[13,14,15]$. Pertambahan penduduk tidak hanya akan berdampak pada jumlah kebutuhan air untuk keperluan domestik, tetapi juga kebutuhan air untuk mendukung berbagai kegiatan manusia dan semakin meningkatnya ancaman yang menyebabkan airtanah menjadi semakin berkurang [16,17]. Ancaman yang dimaksud berupa pencemaran air oleh aktivitas manusia dan intrusi air laut yang disebabkan pemompaan yang berlebih. Kondisi tersebut akan semakin parah apabila terjadi musim kemarau, di mana imbuhan airtanah berupa air hujan tidak tersedia [18]. Penelitian ini bertujuan untuk menganalisis kondisi kualitas airtanah di musim kemarau. Hasil penelitian ini 
diharapkan dapat menjadi masukan dalam perencanaan pengelolaan sumberdaya air di pulau koral sangat kecil di masa mendatang dan dapat digunakan dalam upaya mitigasi kekeringan hidrologis di pulau koral sangat kecil seperti pulau koral panggang.

\section{Methods}

Analisis kualitas air di Pulau Koral Panggang dihasilkan dari analisis kimia, biologi dan fisika sampel airtanah. Sampel airtanah yang digunakan dalam penelitian ini terdiri dari delapan sampel. Delapan sampel ini diambil dari sumur dangkal yang diasumsikan mewakili bagian pinggir pulau koral dan tengah pulau koral. Parameter yang dianalisis meliputi $\mathrm{pH}$, unsur mayor (kalsium, magnesium, natrium, kalium, bikarbonat, sulfat, dan klorida), BOD, COD, total coliform dan daya hantar listrik yang mencerminkan tingkat salinitas airtanah. Baku mutu kualitas air yang digunakan meliputi Peraturan Menteri Kesehatan RI nomor 90 Tahun 2002, Peraturan Pemerintah RI Nomor 20 Tahun 1990 dan standar yang digunakan oleh ahli [19] untuk parameter yang tidak diatur pada peraturan yang disebutkan sebelumnya. Selain itu, dilakukan pula analisis proses yang terjadi dalam airtanah dengan menggunakan diagram piper segitiga dan diagram piper segi empat. Keduanya dapat digunakan untuk menganalisis proses yang terjadi dalam airtanah dengan cukup baik $[13,16,20,21$, 22].

\section{Results and Discussion}

Berdasarkan hasil analisis kualitas airtanah yang dibandingkan dengan beberapa standar baku mutu untuk air minum, diketahui bahwa beberapa parameter telah melebihi ambang batas baku mutu (Tabel 1.). Hal ini menunjukkan kerusakan sumberdaya airtanah di Pulau Koral Panggang telah terjadi. Beberapa parameter yang telah melebihi baku mutu air minum adalah kalsium, magnesium, natrium, kalium, BOD, COD dan Colliform Total (parameter yang melebihi baku mutu di sajikan dengan background warna merah pada Tabel 1). Selain menunjukkan adanya pencemaran airtanah oleh intrusi air laut, hasil analisis kualitas air ini juga menunjukkan bahwa airtanah telah tercemar dari kegiatan manusia (domestik). Kondisi tersebut ditunjukkan dengan terlampauinya ambang batas untuk BOD, COD dan tingginya nilai Coliform total.

Tabel 1. Hasil Analisis Kualitas Airtanah di Pulau Koral Panggang

\begin{tabular}{|c|c|c|c|c|c|c|c|c|c|c|c|}
\hline No. & pH & $\begin{array}{c}\mathrm{Ca}^{2+} \\
(\mathrm{mg} / \mathrm{l})\end{array}$ & $\begin{array}{l}\mathrm{Mg}^{2+} \\
(\mathrm{mg} / \mathrm{l})\end{array}$ & $\begin{array}{c}\mathrm{Na}^{+} \\
(\mathrm{mg} / \mathrm{l})\end{array}$ & $\begin{array}{c}\mathbf{K}^{+} \\
(\mathrm{mg} / \mathrm{l})\end{array}$ & $\begin{array}{c}\mathrm{HCO}_{3}{ }^{2-} \\
(\mathrm{mg} / \mathrm{l})\end{array}$ & $\begin{array}{l}\mathrm{SO}_{4}{ }^{2-} \\
(\mathrm{mg} / \mathrm{l})\end{array}$ & $\begin{array}{c}\mathrm{Cl}^{-} \\
(\mathrm{mg} / \mathrm{l})\end{array}$ & $\begin{array}{l}\text { BOD } \\
(\mathrm{mg} / \mathrm{l})\end{array}$ & $\begin{array}{c}\text { COD } \\
(\mathrm{mg} / \mathrm{l})\end{array}$ & $\begin{array}{c}\text { Total } \\
\text { Coliform }\end{array}$ \\
\hline 1 & 8,13 & 370 & 399 & 495,8 & 59,5 & 380 & 62,1 & 2.680 & 3,32 & 997,00 & 39 \\
\hline 2 & 8,39 & 300 & 832 & 581,3 & 60,7 & 192 & 78,8 & 4.180 & 4,70 & 14,10 & 11 \\
\hline 3 & 7,87 & 280 & 750 & 543,0 & 58,7 & 332 & 61,9 & 3.890 & 10,78 & 32,33 & 22 \\
\hline 4 & 7,93 & 350 & 796 & 422,8 & 60,0 & 324 & 68,5 & 3.910 & 5,43 & 16,29 & Absent \\
\hline 5 & 8,35 & 400 & 881 & 267,4 & 60,0 & 268 & 65,9 & 3.540 & 11,18 & 33,54 & 11 \\
\hline 6 & 8,19 & 320 & 700 & 467,2 & 60,7 & 236 & 70,9 & 3.130 & 5,51 & 16,59 & 4 \\
\hline 7 & 8,44 & 230 & 587 & 537,2 & 58,2 & 228 & 25,8 & 3.200 & 2,27 & 6,81 & 13 \\
\hline 8 & 8,43 & 280 & 556 & 424,0 & 58,2 & 228 & 6,7 & 3.200 & 1,70 & 5,10 & 52 \\
\hline Standards & $6,5-8,5^{\mathrm{a}}$ & $100^{c}$ & $50^{c}$ & $200,00^{\mathrm{a}}$ & $50,00^{\mathrm{c}}$ & $500^{c}$ & $250^{\mathrm{a}}$ & $250^{\mathrm{a}}$ & $6,0^{\mathrm{b}}$ & $10^{\mathrm{b}}$ & Absent $^{\mathrm{b}}$ \\
\hline
\end{tabular}

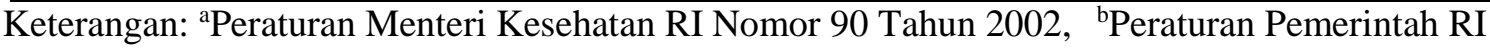
Nomor 20 Tahun 1990, 'Todd dan Mays (2004)

Tingginya nilai kalsium pada airtanah di Pulau Koral Panggang kemungkinan terjadi secara alamiah. Hal ini terjadi pulau di Pulau Koral Pramuka dan Pulau Koral Pari yang secara geologi memiliki kemiripan dari sisi genesis dan material penyusun akuifer [23,24]. Penyusun akuifer utama di Pulau Koral Panggang adalah material bioklastik yang kaya kalsium karbonat [25,26]. Hal inilah yang kemudian menyebabkan kandungan kalsium pada airtanah menjadi tinggi.

Pengaruh intrusi air laut tercermin dari tingginya nilai magnesium, natrium, kalium dan klorida $[21,27,28,29]$. Kandungan yang ion-ion tersebut sangat jauh dibandingkan dengan ambang batas baku mutu untuk air minum. Kandungan klorida misalnya, nilainya mencapai lebih 12 kali dari ambang batas yang diperkenankan untuk air minum. Kondisi ini juga tercermin dari tingginya nilai daya hantar listrik yang tinggi (Gambar 2). 
Hasil pemetaan sebaran salinitas airtanah yang didasarkan pada nilai daya hantar listrik menunjukkan bahwa nilai daya hantar listrik airtanah di Pulau Koral Panggang bervariasi mulai dari $4.500 \mu \mathrm{S} / \mathrm{cm}$ sampai dengan $35.000 \mu \mathrm{S} / \mathrm{cm}$ (Gambar 2.). Nilai daya hantar listrik rendah terdapat di bagian tengah pulau. Hal ini karena wilayah ini kemungkinan terpengaruh air laut dengan derajat pengaruh paling kecil, sehingga nilai daya hantar listrik pada bagian tengah pulau menjadi paling kecil. Pola yang sama ditemukan di Pulau Koral Pramuka dan Pulau Koral Pari [24,30]. Tingginya daya hantar listrik ini juga dipengaruhi oleh banyaknya pengambilan airtanah yang dilakukan di Pulau Koral Panggang, khususnya untuk kepentingan domestik selain minum kebutuhan minum dipenuhi dengan menggunakan air kemasan dari luar pulau koral panggang). Jumlah penduduk yang banyak menyebabkan kebutuhan air sangat banyak dan kemungkinan menyebabkan terjadinya intrusi air laut karena pengambilan airtanah yang berlebihan.

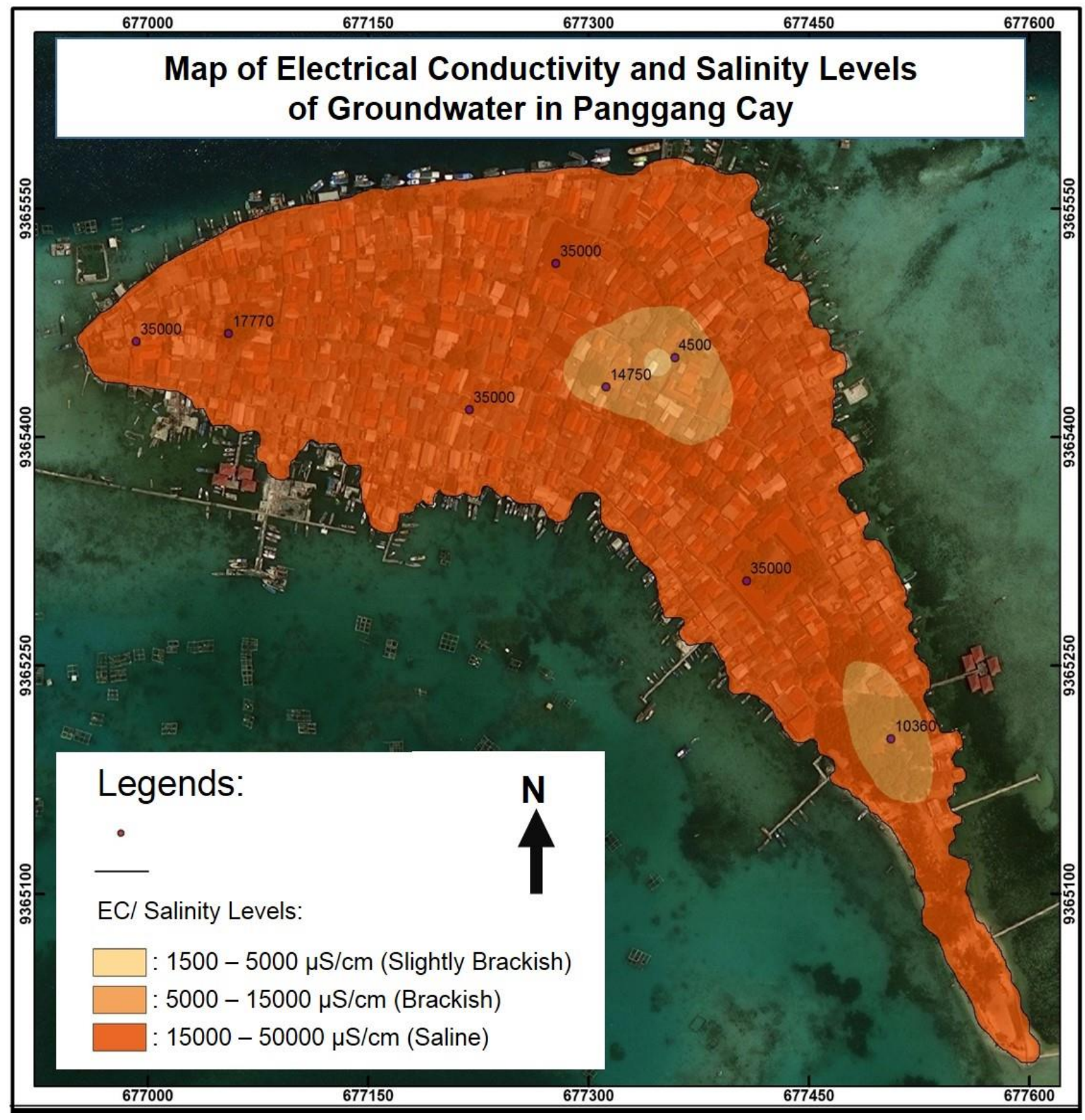

Gambar 2. Sebaran Spasial Nilai DHL dan Tingkat Salinitas Airtanah di Pulau Koral Panggang 
Nilai DHL Pulau Koral Panggang hasil pengukuran kemudian dapat dianalisis dengan membagi kelas nilai DHL berdasarkan klasifikasi tingkat salinitas airtanah berdasarkan nilai DHL. Pembagian dilakukan berdasarkan klasifikasi yang ditampilkan dalam Tabel 2. Hasil analisis menunjukkan bahwa airtanah tawar sudah tidak ditemukan di Pulau Koral Panggang. Tingkat salinitas airtanah di pulau koral ini mulai dari airtanah agak payau sampai dengan airtanah asin (Gambar 2). Berdasarkan tingkat salinitas ini, maka airtanah di Pulau Koral Panggang sudah tidak layak untuk konsumsi (tidak layak untuk air minum).

Tabel 2. Klasifikasi Level Salinitas Berdasarkan Nilai DHL

\begin{tabular}{|l|l|}
\hline \multicolumn{1}{|c|}{ Level of Salinity } & Electric Conductivity $(\boldsymbol{\mu S} / \mathbf{c m})$ \\
\hline Fresh Water & $<1.500$ \\
\hline Slightly Brackish Water & $>1.500-\leq 5.000$ \\
\hline Brackish Water & $>5.000-\leq 15.000$ \\
\hline Saline Water & $>15.000-\leq 50.000$ \\
\hline
\end{tabular}

Hasil analisis dengan menggunakan diagram piper segitiga (Gambar 3), menunjukkan adanya penambahan kalsium dan magnesium dalam airtanah (tipe airtanah $\mathrm{H}$ ). Penambahan magnesium merupakan penciri terjadinya intrusi air laut selain klorida. Selain itu, diagram piper segitiga juga menunjukkan penambahan klorida yang terjadi akibat proses alamiah (tipe airtanah F).

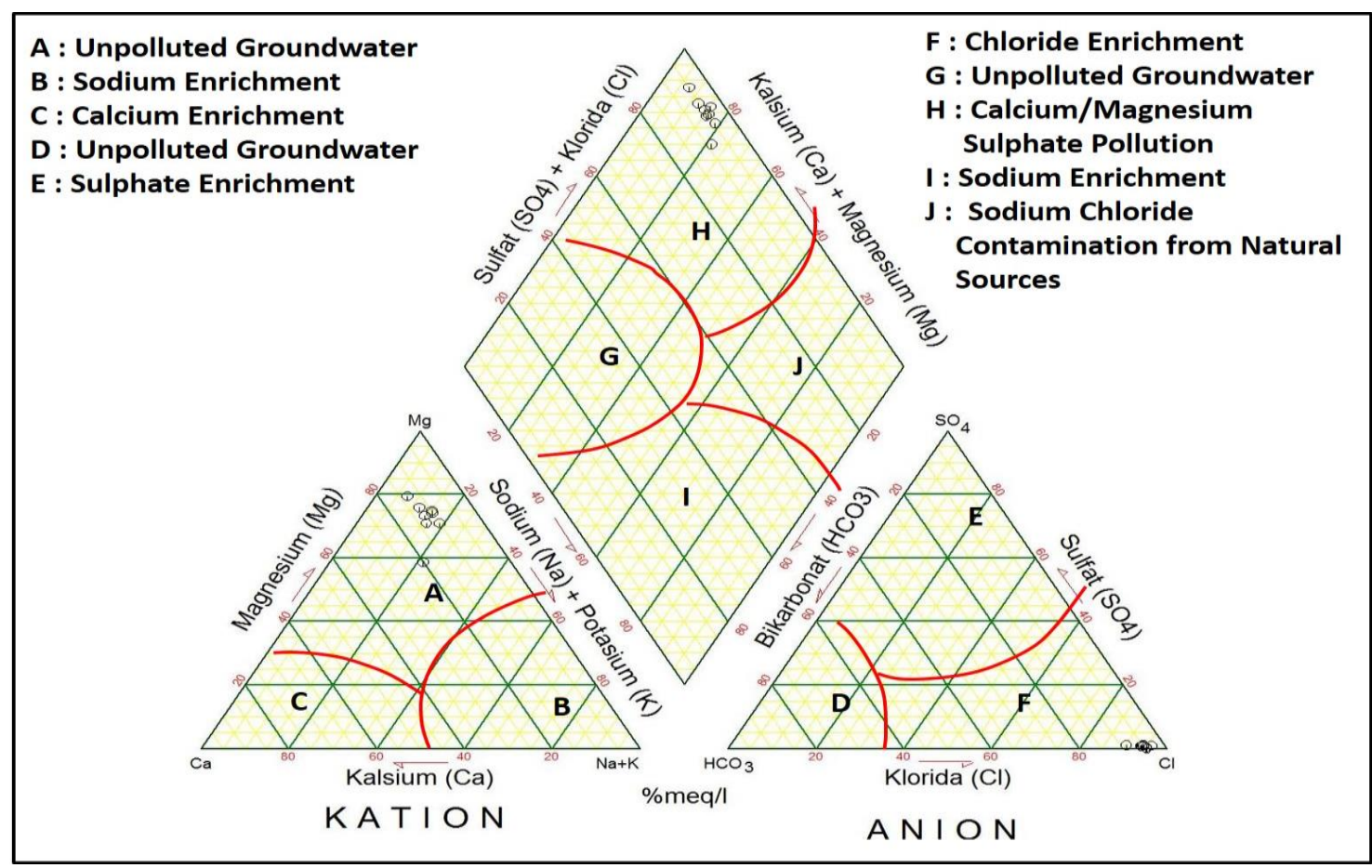

Gambar 3. Diagram Piper Segi Tiga Karakteristik Hidrokimia Airtanah di Pulau Koral Panggang

Hasil analisis dengan diagram piper segi empat juga sangat mendukung hasil pembahasan sebelumnya (Gambar 4). Gambar 4 menunjukkan semua sampel airtanah (titik warna merah) menempati tipe airtanah asin atau tipe VI. Tipe airtanah ini terbentuk oleh adanya proses intrusi air laut. Penelitian lain yang dilakukan di Pulau Koral Panggang pada tahun 2017, Pulau Koral Pramuka dan Pulau Koral Pari menunjukkan proses intrusi air laut telah menyebabkan perubahan tipe air dari $\mathrm{CaCO}_{3}$ menjadi $\mathrm{MgCl}_{2}$ [7,10,23,24,29]. Selain itu, penelitian-penelitian sebelumnya menunjukkan bahwa umumnya pulau koral di Kepulauan Seribu dengan penduduk yang padat telah terpengaruh intrusi air laut dengan kategori sedang samapai dengan sangat berat $[7,10,24]$. 


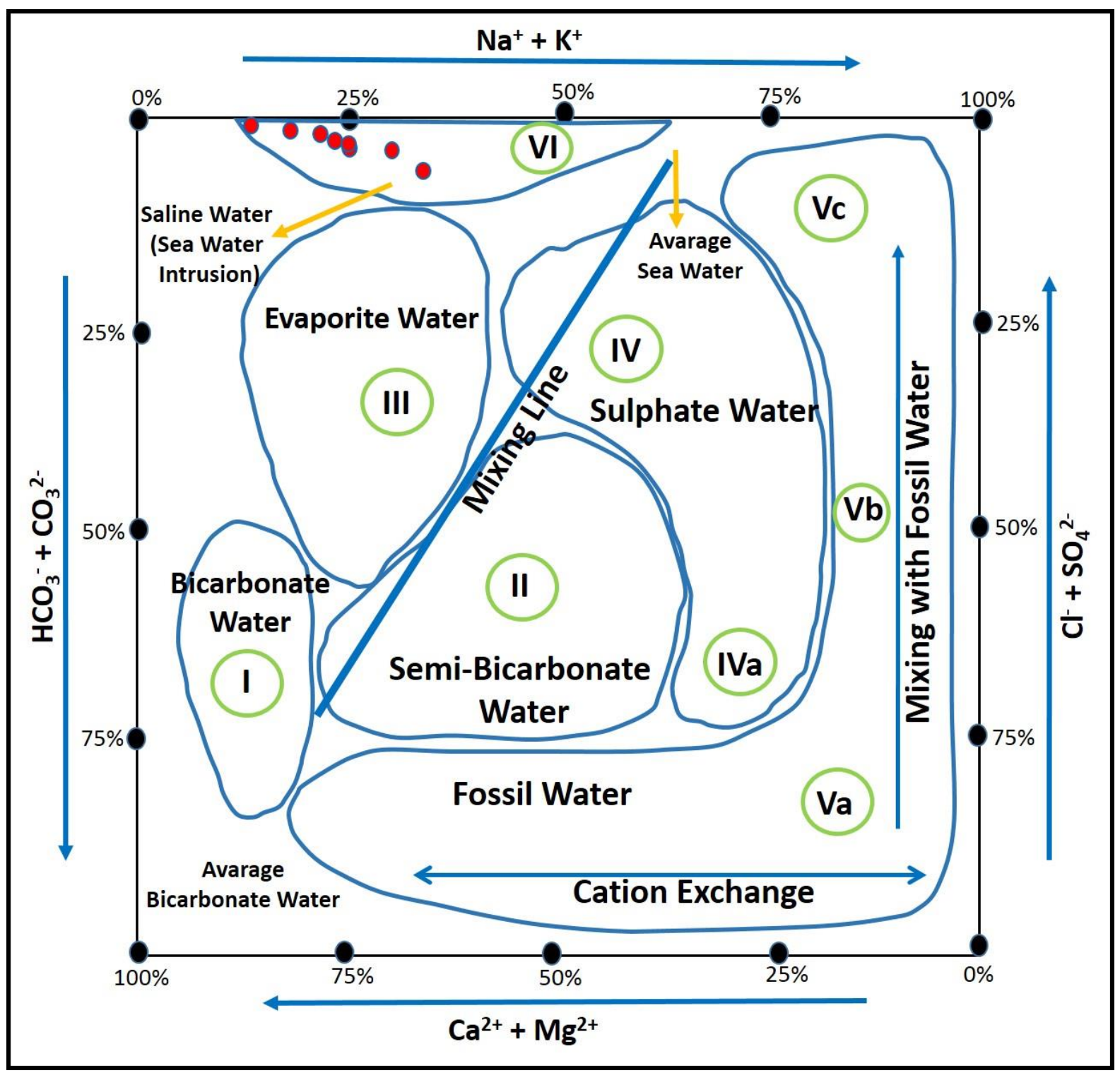

Gambar 4. Diagram Piper Segi Empat Karakteristik Hidrokimia Airtanah di Pulau Koral Panggang

\section{Conclusions}

Berdasarkan hasil analisis yang telah dilakukan, diketahui bahwa airtanah di Pulau Koral Panggang telah mengalami pencemaran. Pencemaran yang terjadi di Pulau Koral Panggang terjadi akibat dari (1) intrusi air laut yang di tandai dengan tingginya kandungan magnesium, natrium, kalium, dan klorida; dan (2) pencemaran limbah domestik yang ditandai dengan tingginya nilai BOD, COD dan total coliform. Pencemaran oleh intrusi air laut dalam penelitian ini dikuatkan dengan hasil analisis diagram piper segi tiga yang menunjukkan adanya pengayaan klorida oleh sebab alamiah dan analisis diagram segi empat yang menunjukkan semua sampel airtanah mengelompok pada tipe airtanah VI (saline water) yang disebabkan oleh intrusi air laut. Berdasarkan hasil di atas, disimpulkan bahwa airtanah yang terdapat di Pulau Panggang saat musim kemarau sudah tidak layak untuk sumber air minum.

\section{References}

[1] Falkland C A 1991 Hydrology and Water Resources of Small Island: A Practica Guide (Paris: Unesco) 
[2] Falkland C A 1993 Hydrology and Water Management in Small Tropical Island Proceeding of The Yokohama Symposium on Hydrology on Warm Humid Region (Yokohama, Japan, 13-15 July 1993)

[3] Gilli E, Mangan C and Mudry J 2012 Hydrogeology: Objectives, Methods, Applications (Boca Raton: CRC Press)

[4] Cahyadi A, Marfai M A, Tivianton T A, Wulandari and Hidayat W 2015 Menyelamatkan Masa Depan Pulau-Pulau Kecil Indonesia Proceeding of the National Geography Meeting 2013 (Yogyakarta: Faculty of Geography, Universitas Gadjah Mada)

[5] Cahyadi A and Tivianton, T A 2013 Persepsi Masyarakat Terhadap Pemanenan Air Hujan dan Dampaknya Terhadap Ketahanan Sumberdaya Air di Pulau Pramuka, Kepulauan Seribu, DKI Jakarta. in Pengelolaan Lingkungan Zamrud Khatulistiwa, ed M A Marfai and M Widyastuti (Yogyakarta: Buku Pintal)

[6] Cahyadi A 2012 Permasalahan Sumberdaya Air di Pulau Karang Sangat Kecil (Studi Kasus di Pulau Pramuka, Kabupaten Kepulauan Seribu, DKI Jakarta) Proceeding of the National Natural Resources and Environmental Management (Semarang: Environmental Science Study Program, Universitas Diponegoro)

[7] Cahyadi A 2015 Analisis Potensi Sumberdaya Air Pulau Koral Sangat Kecil (Studi Kasus di Pulau Koral Pramuka, Kabupaten Kepulauan Seribu, DKI Jakarta) M.Sc. Thesis (Yogyakarta: Master Program on Planning and Management of Coastal Area and Watershed, Faculty of Geography, Universitas Gadjah Mada)

[8] Cahyadi A, Hidayat W and Wulandari 2013. Adaptasi Masyarakat Terhadap Keterbatasan Sumberdaya Air di Pulau Pramuka, Kepulauan Seribu, DKI Jakarta Jurnal Penelitian Kesejahteraan Sosial 12(2) 207 - 213

[9] Arenas A A D and Huertas J F 1986 Hydrology and Water Balance of Small Island: A Review of Existing Knowledge (Paris: UNESCO)

[10] Cahyadi A and Hidayat W 2017 Analisis Karakteristik Hidrogeokimia Airtanah di Pulau Koral Panggang, Kepulauan Seribu, DKI Jakarta Jurnal Geografi 9(2) 99-108

[11] Afadlal, Wijonarko S, Meifina, Septi A, Ongkosongo A E and Ongkosongo O S R 2011 Kondisi Lingkungan Sosial, Ekonomi dan Budaya di Pulau Pramuka, in Rona Lingkungan Pulau Pramuka, ed O S R Ongkosongo, S Wijonarko, and Afadlal (Jakarta: Lembaga Ilmu Pengetahuan Indonesia (LIPI), Pusat Penelitian Oseanografi, Balai Dinamika Laut, Kolompok Penelitian Geologi Laut)

[12] Anggraini D F and Cahyadi A 2013 Analisis Perubahan Penggunaan Lahan dan Pola Adaptasi Masyarakat Terhadap Keterbatasan Lahan di Pulau Panggang Kepulauan Seribu DKI Jakarta Jurnal Geografi 11 123-129

[13] Younger P L 2007 Groundwater in the Environment (Oxford, UK: Blackwell Publishing)

[14] Siebert S, Burke J, Faures J M, Frenken K, Hoogeven J, Dört P and Portmann F T 2010 Groundwater Use for Irrigation- A Global Inventory Hydrology and Earth System Sciences 14 $1864-1880$

[15] Sen Z 2015 Practical and Applied Hydrogeology (Waltham, UK: Elsevier)

[16] Hiscock K M and Bense V F 2014 Hydrogeology: Principles and Practice, Second Edition (Chichester: John Wiley and Sons Ltd.)

[17] Karamouz M, Ahmadi A and Akhbari M 2011 Groundwater Hydrology: Engineering, Planning and Management (Boca Raton: CRC Press)

[18] WWAP (World Water Assessment Programme) 2009 The United Nations World Water Development Report 3: Water in a Changing World (Paris: UNESCO Publishing)

[19] Todd D K and Mays L W 2004 Groundwater Hydrology, Thrid Edition (New York: John Wiley \& Sons)

[20] Hem J D 1970 Study and Interpretation of the Chemical Characteristic of Natural Water (Washington D.C: United State Government Printing Office)

[21] Šráček O and Zeman J 2004 Introduction to Environmental Hydrogeochemistry (Brno: Faculty of Science, Masaryk University) 
[22] Agniy R F and Cahyadi A 2015 Analisis Evolusi Hidrogeokimia Airtanah di Sebagian Mataair Karst Kabupaten Rembang Bagian Selatan Proceeding of the National Seminar on Innovation in Environmental Management (Semarang: Graduate Program, Universitas Diponegoro)

[23] Cahyadi A, Agniy R F and Suhana S N 2015 Karakterisasi Hidrogeokimia Airtanah untuk Analisis Genesis Airtanah di Pulau Koral Sangat Kecil Proceeding of the First National Seminar rosiding on Coastal Area and Watershed Management (Yogyakarta: Master Program on Planning and Management of Coastal Area and Watershed, Faculty of Geography, Universitas Gadjah Mada)

[24] Cahyadi A, Romadhoan F and Sasongko M H 2015 Analisis Neraca Sumberdaya Air Sebagai Arahan Pengembangan Pulau Koral Sangat Kecil (Studi Kasus Pulau Koral Pari, Kabupaten Kepulauan Seribu, DKI Jakarta) Research Report (Yogyakarta. Magister Pengelolaan Pesisir dan Daerah Aliran Sungai, Fakultas Geografi, Universitas Gadjah Mada)

[25] Cahyadi A, Adji T N and Marfai M A 2016 Uji Akurasi Aplikasi Electromagnetic Very Low Frequency (EM VLF) untuk Analisis Potensi Airtanah di Pulau Sangat Kecil. Proceeding of the Second National Seminar rosiding on Coastal Area and Watershed Management (Yogyakarta: Master Program on Planning and Management of Coastal Area and Watershed, Faculty of Geography, Universitas Gadjah Mada)

[26] Custodio E 2005 Coastal Aquifer as Important Natural Hydrogeological Structures. in Groundwater and Human Development, ed E M Bocanegra, M A Hernandez and E Usunoff (Leiden: A.A. Balkema Publisher)

[27] Aris A Z, Praveena S M and Isa N M 2013 Groundwater Composition and Geochemical Controls in Small Tropical Island of Malaysia: A Comparative Study, in Groundwater in The Coastal Zones of Asia-Pacific, ed C Wetzelhuetter (Dordrecht: Springer)

[28] Aris A Z, Abdullah M H, Ahmed A and Woong K K 2007 Controlling Factors of Groundwater Hydrochemistry in A Small Island's Aquifer International Journal of Environmental Science and Technology 4 (4) 441-450

[29] Cahyadi A, Adji T N and Marfai M A 2015 Analisis Evolusi Hidrogeokimia Airtanah di Pulau Koral Pramuka, Kepulauan Seribu Proceeding of National Seminar on Geography (Surakarta: Universitas Muhammadiyah Surakarta)

[30] Cahyadi A, Marfai M A, Tivianton T A, Wulandari and Hidayat W 2013 Analisis Distribusi Spasial Salinitas Airtanah di Pulau Pramuka, Kepulauan Seribu, DKI Jakarta Proceeding on National on Geospatial Information Utilization (Surakarta: Universitas Muhammadiyah Surakarta)

[31] Suherman D 2007 Mata Air Sebagai Sumber Air Bersih di Pulau Kai-Kecil, Maluku Tenggara, in Sumber Daya Air di Pulau Kecil, ed P E Hehanusa and H Bhakti (Bandung: LIPI Press)

Paper ini adalah versi preprint dari makalah kami yang dipresentasikan dalam "International Conference on Earth Science, Mineral and Energy 2018" di UPN Veteran Yogyakarta pada tanggal 11-13 Oktober 2018. Edisi terbit dari makalah ini berbahasa Inggris berjudul "Groundwater Quality Analysis in Dry Seasons in Panggang Cay, Kepulauan Seribu, Jakarta" 